Jurnal Kajian Bahasa, Sastra, dan Pe

Volume 3, Nomor 1, Februari 2020, Halaman 53-64

p-ISSN 2615-725X (Print) e-ISSN 2615-8655 (Online)

http://diglosiaunmul.com/index.php/diglosia/article/view/49

\title{
MANAJEMEN BAHASA PENULISAN PROPOSAL MAHASISWA NONKEBAHASAAN
}

\section{The Language Management of Writing Proposals of Non-Language Students}

\author{
Widyatmike Gede Mulawarman ${ }^{1, *} \&$ Nanda Noviyanti ${ }^{2}$ \\ ${ }^{1}$ Fakultas Keguruan dan Ilmu Pendidikan, Universitas Mulawarman \\ ${ }^{2}$ Pendidikan Bahasa Indonesia, FKIP, Universitas Mulawarman \\ 1,*Pos-el korespondensi: widyatmike@ffkip.unmul.ac.id \\ ${ }^{2}$ Pos-el: nandanovi494@gmail.com
}

\begin{abstract}
This research raised the issue of language management as (1) the planning process in determining the vision and mission of writing a proposal (formulating a topic), (2) organizing (compiling the proposal writing structure as effectively as possible), (3) conducting a leadership strategy, that is, a strategy related to motivating, influencing and directing the reader, and (4) controlling (editing or editing the proposal writing). These four aspects of language management are focused on the use of Indonesian in proposals in terms of (1) sentence structure, (2) structure, (3) meaning/diction, and (4) writing. The subject of this study was a student proposal from the Faculty of Economics, Mulawarman University. Data in the form of language management, namely the planning process of writing proposals to editing student proposals is collected by the documentation method. To strengthen the classification of variations in language use on proposals, validation is carried out from experts in the field of error analysis or in the field of applied linguistics. Data in the form of eleven proposals from the Faculty of Economics students were analyzed using descriptive analysis methods. The results showed that in the proposal writing of non-linguistic students had fulfilled the four aspects of language management (style of environment of the faculty of economics) namely, the stages of planning, organizing, writing, and editing. In addition to paying attention to writing management, writing a proposal also has writing characteristics. Krakteristik is the ballmark of an idea both in writing and presentation. Characteristics contain facts, contain both title and problem descriptions, use of theory, problem solving and conclude. found a variety of deviations in the use of language, both relating to the sentence structure, the formations, the order of meaning/diction, and writing.
\end{abstract}

Keywords: language management, the process of planning, organizing, writing, editing proposals

Abstrak: Penelitian ini mengangkat permasalahan manajemen bahasa sebagai (1) proses perencanaan dalam menentukan visi dan misi penulisan proposal (merumuskan topik), (2) melakukan pengorganisasian (menyusun struktur tulisan proposal seefektif mungkin), (3) melakukan strategi kepemimpinan, yaitu strategi yang berkaitan dengan memotivasi, mempengaruhi dan mengarahkan pembaca, dan (4) melakukan pengendalian (mengedit atau menyunting tulisan proposal). Keempat aspek manajemen bahasa ini difokuskan pemakaian bahasa Indonesia pada proposal ditinjau dari segi (1) tata kalimat, (2) tata bentukan, (3) tata makna/diksi, dan (4) tata tulis. Subjek penelitian ini adalah proposal mahasiswa Fakultas Ekonomi Universitas Mulawarman. Data berupa manajemen bahasa, yakni proses perencanaan tulisan proposal sampai dengan pengeditan proposal mahasiswa dikumpulkan dengan metode dokumentasi. Untuk memperkuat penggolongan ragam penyimpangan pemakaian bahasa pada proposal, maka dilakukan validasi dari pakar dalam bidang analisis kesalahan atau dalam bidang linguistik terapan. Data yang telah tersedia berupa 11 proposal mahasiswa Fakultas Ekonomi dianalisis dengan menggunakan metode analisis deskriptif. Hasil penelitian menunjukkan bahwa dalam penulisan proposal mahasiswa nonkebahasaan telah memenuhi empat aspek manajemen bahasa (gaya selingkung Fakultas Ekonomi), yaitu tahapan perencanaan, pengorganisasian, penulisan, dan pengeditan. Selain memperhatikan manajemen penulisan, dalam menulis proposal juga memiliki karakteristik 
penulisan. Karakteristik adalah ciri khas suatu gagasan baik dalam penulisan dan penyajiannya. Karakteristik memuat fakta, berisi uraian baik judul dan permasalahan, penggunaan teori, pemecahan masalah dan menyimpulkan. ditemukan aneka ragam penyimpangan pemakaian bahasa, baik yang menyangkut tata kalimat, tata bentukan, tata makna/diksi, maupun tata tulis.

Kata kunci: manajemen bahasa, proses perencanaan, pengorganisasian, penulisan, pengeditan proposal

\section{A. PENDAHULUAN}

Bahasa Indonesia masih diprogramkan sebagai mata kuliah Pengembangan Kepribadian di tingkat perguruan tinggi terutama bagi mahasiswa nonkebahasaan. Mata kuliah Bahasa Indonesia biasanya diprogramkan di semester awal dan mahasiswa wajib mengambil mata kuliah Bahasa Indonesia sebagai penguatan dalam penulisan tugas akhir berupa skripsi di program strata S1. Dari sudut pragmatis bila dicermati bahasa Indonesia (BI) telah dipelajari sejak di sekolah SD hingga SMA tak pernah beranjak dari persoalan "kesulitan dalam memahami" apalagi bahasa Indonesia di tingkat SMA menjadi salah satu mata pelajaran yang diujikan pada saat ujian nasional. Kesulitan memahami juga dialami mahasiswa kita yang merasa alergi dengan mata kuliah Bahasa Indonesia sehingga menjadi kendala dalam kegiatan belajar mengajar terutama menulis.

Menulis merupakan suatu kegiatan komunikasi berupa penyampaian pesan atau informasi secara tertulis kepada pihak lain dengan menggunakan bahasa tulis sebagai alat atau medianya. Aktivitas menulis melibatkan beberapa unsur, yaitu penulis sebagai penyampaian pesan, isi tulisan, saluran atau media, dan pembaca.

Meyakinkan pembaca atau sekedar sebagai media untuk menghibur para pembaca. Hasil dari proses kreatif ini dapat disebut dengan istilah karangan atau tulisan. Menurut Suparno \& Yunus, menulis merupakan suatu kegiatan penyampaian pesan (komunikasi) dengan menggunakan bahasa tulis sebagai alat atau medianya (Dalman, 2016, hal. 13). Kegiatan penyampaian pesan dalam hal ini adalah menyampaikan mengenai infromasi yang didapat dari hasil penelitian ataupun pengkajian mengenai masalah. Dituangkan dalam bentuk tulisan agar dapat dibaca dan mudah diterima oleh masyarakat ataupun kalangan pembaca.

Kegiatan menulis dapat banyak menghasilkan produk tulisan salah satunya bersifat ilmiah. Salah satu dari produk menulis adalah Karya tulis ilmiah. Kisworo \& Sofana (2017, hal. 29) menyebutkan bahwa karya ilmiah menyajikan gagasan, ide-ide, pemikiran yang dituangkan secara sistematis menggunakan unsur-unsur yang telah diatur menurut kaidah tertentu. Dalman (2016, hal. 5) menambahkan bahwa karya ilmiah merupakan karya tulis yang isinya berusaha memaparkan suatu pembahasan secara ilmiah yang dilakukan oleh seorang penulis atau peneliti. Perlu diketahui pemaparan karya tulis ilmiah dari beberapa pendapat di atas dapat disimpulkan bahwa karya ilmiah merupakan salah satu hasil produk dari menulis yang dituangkan secara sistematis dalam penulisannya dan merupakan hasil pemikiran yang didasarkan pada fakta adanya peristiwa atau gejala disampaiakan dengan akurat serta dapat dipertanggungjawabkan. Adapun ciri yang diperhatikan dalam karya tulis ilmiah, yaitu fakta, definisi, menguraikan masalah, teori, dan pemecahan masalah. Beberapa wujud dari hasil karya tulis ilmiah antara lain makalah, artikel, laporan penelitian dan proposal.

Penulisan pada karya tulis ilmiah tidak terlepas dari beberapa tahapan. Tahapan-tahapan tersebut dapat dikatakan sebagai manajemen. Pada 
prosesnya tahapan karya tulis ilmiah memuat beberapa tahapan yang terorganisir hal ini dapat dikenal dengan manajamen. Manajemen adalah suatu proses khas yang terdiri atas tindakantindakan perencanaa, pengorganisasian, penggerakan dan pengendalian yang dilakukan untuk menentukan serta mencapai sasaran yang telah ditentukan melalui pemanfaatan sumber daya manusia dan sumber-sumber daya lainya. Manajemen memiliki fungsi perencanaan, pelaksanaan, dan evaluasi (Agustrian et al., 2018, hal. 7). Manajemen bisa kita jumpai pada penuisan karya tulis ilmiah, dalam penulisan karya tulis ilmiah haruslah diperhatikan. Karena untuk membuat suatu karangan atau karya tulis yang baik dan untuk mudah diterima pembaca, perhatian sangat di tekankan pada isi yang akan dibahas dan bagaimana penulisan yang disajikan. Haruslah mengalami kesesuaian dengan kaidah-kaidah penulisan pada bahasa Indonesia.

Menurut Dalman (2016, hal. 5) beberapa tahapan yang menjadi manajemen dalam penulisan karya tulis antara lain tahapan persiapan, tahapan penulisan dan tahapan pengeditan atau penghalusan. Tahap persiapan adalah tahapan yang menentukan fokus isi tulisan yang akan dikaji, biasanya pada tahap penulisan penulis dapat menggunakan metode Braind Stroming dan Mind Mapping. Metode Braind Stroming dan Mind Mapping Adalah menuangkan semua ide-ide atau gagasan untuk diseleksi kembali gagasan gagasannya. Tahapan penulisan adalah tahapan yang berisi sistematika penulisan yang memuat bagian awal sampai akhir. Tahapan pengeditan atau pengahalusan adalah tahapan akhir yang berisi kegiatan perbaikan atau penyuntingan yang bertugas sebagai sistem untuk memperbaiki unsur mekanik karangan karya tulis ilmiah. Proposal merupakan salah satu dari jenis karya tulis ilmiah yang berisi mengenai suatu masalah yang mengacu pada topik tertentu dengan adanya berupa data yang didapatkan di lapangan untuk melakukan analisis yang bersifat logis dan objektif dalam pengelolaannya. Data yang akan digunakan dalam penelitian haruslah sesuai dengan data yang terdapat di lapangan karena dalam melakukan penelitian harus sesuai dengan fakta yang ada.

Proposal menjadi salah satu hasil produk menulis secara ilmiah. Penulisan sebuah karya tulis ilmiah tidak terlepas dari karakteristik yang menjadi ciri khas sebuah karya tulis ilmiah. Beberapa ke khasan atau ciri yang terdapat dalam karya tulis ilmiah antara lain memuat, fakta, uraian pengertian judul dan permasalahan, menguraikan masalah, menerapkan teori, pemecahan masalah, dan kesimpulan.

Fakultas Ekonomi Universitas Mulawarman merupakan salah satu fakultas yang terdapat di universitas mulawarman yang memiliki tiga jurusan program studi, yaitu program Manajemen, Akuntansi dan Ilmu Ekonomi Sosial Pembangunan. Pemilihan proposal mahasiswa Fakultas Ekonomi didasarkan oleh Fakultas Ekonomi yang merupakan salah satu fakultas nonkebahasaan yang terdapat di Universitas Mulawarman. Berdasarkan latar belakang di atas, maka penulis memilih judul Manajemen Bahasa Penulisan Proposal Mahasiswa Nonkebahasaan.

Berdasarkan latar belakang di atas tujuan penelitian ini adalah untuk mendeskripsikan (1) proses perencanaan visi dan misi penulisan proposal mahasiswa Fakultas Ekonomi Universitas Mulawarman, (2) pengorganisasi struktur bahasa proposal mahasiswa Fakultas Ekonomi Universitas Mulawarman, (3) penulisan proposal mahasiswa Fakultas Ekonomi Universitas Mulawarman, dan (4) proses pengeditan penulisan proposal mahasiswa Fakultas Ekonomi Universitas Mulawarman. 


\section{B. METODE}

Sesuai dengan permasalahan yang diangkat, penelitian ini menggunakan rancangan deskriptif kualitatif. Kegiatan penelitian manajemen bahasa proposal mahasiswa Fakultas Ekonomi Universitas Mulawarman dilakukan dengan menggunakan metode seperti berikut.

1. Membaca

Teknik baca merupakan teknik peneliti harus membaca terlebih dahulu mengenai sampel yang akan menjadi data penelitian. Teknik baca merupakan teknik atau langkah awal dalam teknik pustaka. Teknik baca sendiri merupakan teknik membaca seperti biasa atau membaca sebuah bacaan pada umumnya. Dengan membaca diharapkan peneliti dapat melihat serta memahami isi dari proposal mahasiswa fakultas ekonomi Universitas Mulawarman untuk menemukan kesesuaian sistematika penulisan karya tulis ilmiah.

2. Menyimak

Teknik simak merupakan suatu metode yang digunakan dalam penyediaan data dengan cara peneliti melakukan penyimakan penggunaan atau perilaku dalam pembelajaran bahasa. Dalam hal ini penyimakan yang dimaksud adalah peneliti menyimak mengenai apa yang ditulis pada data yang akan dikaji dalam penelitian. Penyimakan ini bisa saja dari hasil penulisan atau kalimat-kalimat yang di tulis atau perilaku yang menjadi sumber data. Tujuan dari teknik simak dalam penelitian ini bertujuan untuk mempelajari dengan teliti objek yang akan diteliti.

3. Mencatat

Pada teknik catat digunakan untuk mencatat atau menggaris bawahi datadata yang penting atau hal yang menjadi sorotan dalam objek yang akan diteliti setelah melakukan teknik baca dan teknik simak.
4. Wawancara

Pada teknik wawancara digunakan untuk mencari suatu yang biasanya berupa pertanyaan-pertanyaan. Guna untuk mendapatkan informasi lebih langsung dari sumbernya.

Kegiatan melakukan analisis karya tulis ilmiah berupa proposal mahasiswa Fakultas Ekonomi. Peneliti menggunakan proses analisis menggunakan cara berdasarkan teori Miles \& Huberman, teori ini bersifat interaktif. Interaktif disini dapat diartikan, yaitu saling berhubungan atau saling berkaitan antara data satu dan data lainnya. Jadi penganalisisan menggunakan teori Miles \& Huberman yang terdiri dari proses reduksi, penyajian data, dan penarikan kesimpulan. Dalam proses reduksi data peneliti melakukan kegiatan mencatat mengenai data-data yang ditemukan pada tahap ini juga peneliti data memilah-milah mengenai data yang dianggap relevan. Selanjutnya proses penyajian, yaitu proses peneliti akan melakukan analisis data berdasarkan temuan data sebelumnya dalam hal ini peneliti akan menyajikan hasil analisis berupa data yang bersifat naratif yang didukung dengan hasil berupa konteks.

\section{PEMBAHASAN}

Dalam penyajian data dan analisis data, penulis langsung berada di lokus penelitian, yaitu Fakultas Ekonomi dan Bisnis Universitas Mulawarman. Mendata mahasiswa Fakultas Ekonomi dan Bisnis. Dari data tersebut penulis mengambil sebanyak 11 proposal yang akan dijadikan sebagai bahan analisis. Setelah dianalisis penulis mengambil tiga sampel yang banyak ditemukan ketidaktepatan dalam manajemen pengintegrasian dan karakteristik karya tulis ilmiah yang ditulis oleh mahasiswa Fakultas Ekonomi dan Bisnis Universitas Mulawarman. 
Tabel 1. Data Mahasiswa Fakultas Ekonomi dan Bisnis

\begin{tabular}{clc}
\hline No & \multicolumn{1}{c}{ Nama Mahasiswa } & Jurusan \\
\hline 1 & Winda Pratiwi & Akuntansi \\
2 & Ikrar Hakiki & Akuntansi \\
3 & Rizky Nur Ramadhani & Akuntansi \\
4 & Puspita Sari Ramadhani & Akuntansi \\
5 & Monalisa Rusli & Akuntansi \\
6 & Florentina Iin Cristanty Ude & Akuntansi \\
7 & Elfiana Septiya Rini & Manajemen \\
8 & Meydina Werdani & Manajemen \\
9 & Ratnawati & Manajemen \\
10 & Triana Puspita Sari & IESP \\
11 & Damam Dwi Prasetyo & IESP \\
\hline
\end{tabular}

Tabel 2. Data 1 Manajemen Penulisan Proposal (Proposal dengan nama penulis WP)

\begin{tabular}{|c|c|c|c|}
\hline No & Tahap Persiapan & Terdapat Data & $\begin{array}{c}\text { Tidak } \\
\text { Terdapat Data }\end{array}$ \\
\hline 1 & Mengajukan judul sebagai bahan penelitian & $\checkmark$ & - \\
\hline 2 & Mencari topik penelitian yang dikuasai & $\checkmark$ & - \\
\hline 3 & $\begin{array}{l}\text { Meyakinkan bahan bacaan terkait topik yang mudah } \\
\text { diperoleh atau mudah diakses }\end{array}$ & $\checkmark$ & - \\
\hline 4 & $\begin{array}{l}\text { Persempit agar penelitian berfokus dan tuntas } \\
\text { pembahasannya }\end{array}$ & $\checkmark$ & - \\
\hline 5 & $\begin{array}{l}\text { Mengumpulkan data dan informasi selengkap } \\
\text { mungkin dari berbagai sumber }\end{array}$ & $\checkmark$ & - \\
\hline 6 & $\begin{array}{l}\text { Menelusuri sisi apa yang belum diteliti oleh peneliti } \\
\text { lain }\end{array}$ & $\checkmark$ & - \\
\hline 7 & $\begin{array}{l}\text { Bacalah hasil-hasil penelitian terdahulu terkait topik } \\
\text { yang relevan minimal limatahun kebelakang }\end{array}$ & $\checkmark$ & - \\
\hline \multirow[t]{3}{*}{8} & Perhatikan sistematika penulisan proposal & $\checkmark$ & - \\
\hline & Penulisan & $\checkmark$ & - \\
\hline & Pengeditan & $\checkmark$ & - \\
\hline
\end{tabular}

Tabel 3. Perencanaan Penulisan Proposal

\begin{tabular}{cll}
\hline No. & \multicolumn{1}{c}{ Identifikasi } & Bukti \\
\hline 1 Judul & & \\
1. Penggunaan huruf kapital pada & ANALISIS PENERAPAN PEMENDAGRI NOMOR \\
judul. Pada Fakultas Ekonomi & 113 TAHUN 2014 TENTANG PENGELOLAAN \\
penulisan judul ditulis huruf kapital & KEUANGAN DESA PADA DESA MANUNGGAL \\
font Arial dengan ukuran huruf 11 & JAYA KECAMATAN TENGGARONG SEBERANG \\
2. Logis & \\
$\begin{array}{l}\text { 3. Berbentuk frasa } \\
\text { 4. Mengarah pokok permasalahan }\end{array}$ & \\
5. Tidak menggunakan tanda baca & \\
Mencari topik penelitian & Peneliti dengan nama penulis WP merupakan mahasiswa \\
1. Peneliti harus menguasai prinsip & jurusan Akuntasi di Fakultas Ekonomi Universitas \\
ilmiah & Mulawarman. Pembahasan topik yang dibahas peneliti \\
2. Topik berada disekitar peneliti & mengenai pengelolaan keuangan desa. \\
3. objektif &
\end{tabular}


3 Meyakinkan bahan bacaan terkait topik yang mudah diperoleh atau mudah diakses

1. Bersifat lugas

2. Mengandung fakta "menerapkan Peraturan Menteri Dalam Negeri (Permendagri) nomor 113 tahun 2014, yaitu sering terlambatnya proses pelaporan dan pertanggungjawaban keuangan desa yang di sebabkan oleh latar belakang pendidikan perangkat desa yang tidak sesuai dengan bidang ilmunya"

Adanya data yang ditemukan di lapangan mengenai dana pengelolaan Desa

“di Desa Manunggal Jaya, yaitu 13 (tiga belas) RT berada di Dusun Telaga Kencana dan 10 (sepuluh) RT berada di Dusun Sumber Jaya. Desa Manunggal Jaya dengan luas 17.100 Hal ini menjadi pusat pemerintahan bagi Kecamatan Tenggarong Seberang, hal ini didukung oleh bangunan operasional kecamatan yang berada di Desa Manunggal Jaya. Pada tahun 2017, total dana yang dikelola oleh Desa Manunggal Jaya sebesar Rp.2.128.761.816 yang berasal dari empat sumber, yaitu dana desa sebesar Rp.829.193.429, alokasi dana desa sebesar Rp.1.210.169.269, bagian dari hasil pajak dan retribusi daerah sebesar Rp.42.630.818 dan pendapatan asli desa sebesar Rp.46.768.300.”

4 Persempit agar penelitian berfokus dan tuntas pembahasannya

1. Memiliki garis besar yang menjadi dasar utama penelitian

5 Pastikan topik bermanfaat dan merupakan prioritas yang harus dipecahkan

1. Dapat mrngedukasi

2. Dapat berisi informasi

6 Mengumpulkan data dan informasi selengkap mungkin dari berbagai sumber

Seharusnya berdasarkan Peraturan Menteri Dalam Negeri (Permendagri) nomor 113 tahun 2014 disebutkan bahwa perangkat desa wajib menyampaikan laporan pertanggungjawaban keuangan desa secara tertulis kepada masyarakat dengan media informasi yang mudah diakses, contohnya melalui pemasangan baliho atau melalui papan pengumuman. Hal ini dilakukan agar perangkat desa di Desa Manunggal Jaya dapat menerapkan salah satu asas di dalam pengelolaan keuangan desa, yaitu asas transparan kepada masyarakat.

dapat menerapkan ilmu dan teori yang diperoleh pada saat mengikuti perkuliahan dengan permasalahan yang ada, sehingga terciptanya keselarasan antara pengetahuan secara teoritis dan praktik khususnya mengenai akuntansi desa.

sebagai referensi bahan bacaan dalam rangka perbaikan proses penerapan peraturan pemerintah mengenai pengelolaan keuangan desa apabila masih ada yang belum sesuai.

pemilihan responden penelitian berdasarkan peran dan keterlibatannya dalam penerapan Peraturan Menteri Dalam Negeri (Permendagri) nomor 113 tahun 2014 di Desa Manunggal Jaya Kecamatan Tenggarong Seberang.

$7 \quad$ Menelusuri sisi apa yang belum diteliti oleh peneliti lain

Yang belum diteliti oleh peneliti lain adalah pengelolaan keuangan desa di Desa Manunggal Jaya Kecamatan Tenggarong Seberang telah sesuai dengan pengelolaan keuangan desa menurut Peraturan Menteri Dalam Negeri (Permendagri) Nomor 113 Tahun 2014

8 Bacalah hasil-hasil penelitian terdahulu Penelitian merupakan penelitian baru terkait topik yang relevan minimal lima tahun ke belakang 
9 Perhatikan sistematika penulisan proposal

Penulisan

Berisi judul, pendahuluan, rumusan masalah, tujuan penelitian, manfaat penelitian, kajian literatur, metode penelitian, tidak berisi jadwal penelitian, daftar acuan, plagiarisme

Pengeditan Perbaikan yang dilakukan peneliti sebanyak 7 kali baik bab 1 dipertajam, bab 2 melanjutkan kajian pustaka, bab 3 revisi, membuat kuesioner, perbaikan alat analisis dan perjelas saran dan masukan.

\section{Tabel 4. Bagian-Bagian Sistematika Penulisan}

\begin{tabular}{llcc}
\hline No & \multicolumn{1}{c}{ Sistematika Proposal } & Terdapat Data & $\begin{array}{c}\text { Tidak terdapat } \\
\text { Data }\end{array}$ \\
\hline 1 & Judul & $\checkmark$ & \\
2 & Pendahuluan & $\checkmark$ & \\
3 & Rumusan Masalah & $\checkmark$ & \\
4 & Tujuan Penelitian & $\checkmark$ & \\
5 & Manfaat Penelitian & $\checkmark$ & $\checkmark$ \\
6 & Kajian Literatur & $\checkmark$ & \\
7 & Metode Penelitian & $\checkmark$ & \\
8 & Jadwal penelitian & $\checkmark$ & \\
9 & Daftar Acuan & & \\
10 & Plagiarisme & & \\
\hline
\end{tabular}

Tabel 5. Karakteristik Karya Tulis Ilmiah

\begin{tabular}{|c|c|c|c|}
\hline No & Karakteristik & \multicolumn{2}{|c|}{ Cara Penyajian } \\
\hline 1 & Menyajikan fakta & $\begin{array}{l}\text { Objektif } \\
\text { Sistematis } \\
\text { Cermat }\end{array}$ & $\checkmark$ \\
\hline 2 & $\begin{array}{l}\text { Menyajikan pengertian, judul, dan } \\
\text { permasalahan }\end{array}$ & $\begin{array}{l}\text { Dekripsi } \\
\text { Eksplikasi } \\
\text { Analisis } \\
\text { Perbandingan } \\
\text { Etimologi }\end{array}$ & $\checkmark$ \\
\hline 3 & Menguraikan masalah & $\begin{array}{l}\text { Abstrak } \\
\text { Bernalar } \\
\text { Objektif } \\
\text { Konseptual }\end{array}$ & $\checkmark$ \\
\hline 4 & Menerapkan teori & $\begin{array}{l}\text { Faktual } \\
\text { Spesifik }\end{array}$ & $\checkmark$ \\
\hline 5 & Simpulan & $\begin{array}{l}\text { Induktif } \\
\text { Deduktif }\end{array}$ & $\checkmark$ \\
\hline
\end{tabular}

Tabel 6. Uraian Karakteristik Karya Tulis Ilmiah 


\begin{tabular}{|c|c|c|c|}
\hline No & Karakteristik & Penyajian & Contoh \\
\hline 1. & Menyajikan fakta & Objektif & $\begin{array}{l}\text { Penerapan mekanisme pengelolaan keuangan desa secara } \\
\text { baik dan benar sangat di butuhkan, sebab apabila } \\
\text { mekanisme pengelolaan keuangan desa tidak diterapkan } \\
\text { dengan baik dan benar maka perangkat desa akan kesulitan } \\
\text { untuk mengelola dan merealisasikan rencana yang telah } \\
\text { disusun menjadi program-program desa yang akan } \\
\text { dilaksanakan ke depannya serta akan terhambat dalam } \\
\text { proses penyusunan pelaporan dan pertanggungjawaban } \\
\text { keuangan desa. }\end{array}$ \\
\hline 2. & $\begin{array}{l}\text { Uraian } \\
\text { pengertian, judul, } \\
\text { dan permasalahan }\end{array}$ & Deskripsi & $\begin{array}{l}\text { Hasil wawancara awal dengan perangkat desa yang ada di } \\
\text { Desa Manunggal Jaya, kendala yang dihadapi oleh Desa } \\
\text { Manunggal Jaya dalam menerapkan Peraturan Menteri } \\
\text { Dalam Negeri (Permendagri) nomor } 113 \text { tahun 2014, yaitu } \\
\text { sering terlambatnya proses pelaporan dan } \\
\text { pertanggungjawaban keuangan desa yang di sebabkan oleh } \\
\text { latar belakang pendidikan perangkat desa yang tidak sesuai } \\
\text { dengan bidang ilmunya sehingga pekerjaan yang dilakukan } \\
\text { membutuhkan waktu yang lebih lama. }\end{array}$ \\
\hline 3. & $\begin{array}{l}\text { Menguraikan } \\
\text { masalah }\end{array}$ & Objektif & $\begin{array}{l}\text { kendala yang dihadapi oleh Desa Manunggal Jaya dalam } \\
\text { menerapkan Peraturan Menteri Dalam Neger } \\
\text { (Permendagri) nomor } 113 \text { tahun 2014, yaitu sering } \\
\text { terlambatnya proses pelaporan dan pertanggungiawaban } \\
\text { keuangan desa yang di sebabkan oleh latar belakang } \\
\text { pendidikan perangkat desa yang tidak sesuai dengan bidang } \\
\text { ilmunya sehingga pekerjaan yang dilakukan membutuhkan } \\
\text { waktu yang lebih lama. Faktor lain yang menyebabkan } \\
\text { perangkat desa sering terlambat dalam proses pelaporan } \\
\text { dan pertanggungjawaban keuangan desa, yaitu karena } \\
\text { keterlambatan pencairan dana oleh pemerintah, } \\
\text { sehingga memunculkan permasalahan sebagai berikut: } \\
\text { "Apakah pengelolaan keuangan desa di Desa Manunggal } \\
\text { Jaya Kecamatan Tenggarong Seberang telah sesuai dengan } \\
\text { pengelolaan keuangan desa menurut Peraturan Menteri } \\
\text { Dalam Negeri (Permendagri) Nomor } 113 \text { Tahun 2014?" }\end{array}$ \\
\hline 4. & Menerapkan teori & Faktual & $\begin{array}{l}\text { Menurut Peraturan Menteri Dalam Negeri (Permendagri) } \\
\text { nomor } 113 \text { tahun 2014, pengelolaan keuangan desa } \\
\text { merupakan keseluruhan kegiatan yang meliput } \\
\text { perencanaan, penganggaran, penatausahaan, pelaporan, } \\
\text { pertanggungjawaban dan pengawasan keuangan desa. }\end{array}$ \\
\hline 5. & Simpulan & Induktif & $\begin{array}{l}\text { Memaparkan uraian mengenai permasalahan mekanisme } \\
\text { pengelolan keuangan desa dengan merujuk ke dalam hal- } \\
\text { hal yang khusus lalu menjabarkannya ke dalam uraian yang } \\
\text { bersifat umum dalam penggunaan Pemendagri No. } 113 \\
\text { Tahun } 2014\end{array}$ \\
\hline
\end{tabular}

Dalam penelitian ini terdapat 11 data yang penulis kumpulkan, 10 data proposal ini merupakan proposal perwakilan dari 3 jurusan di Fakultas Ekonomi, seperti proposal penelitian mengenai Akuntansi, Manajemen Pembangunan, dan Ilmu Ekonomi Studi
Pembangunan. Dari 11 data penulis mengambil tiga proposal yang dianalisis, tiga proposal tersebut dijadikan bahan penelitian karena dilihat dari tiga kriteria topik seperti topik penelitiannya yang membahas mengenai penelitian Akuntansi, Manajemen dan IESP, selain 
topik penelitiannya dilihat dari lembar konsultasi yang dipegang oleh masingmasing mahasiswa, kemudian dari ketiga data tersebut yang penulis analisis mengenai manajemen pengintegrasian dan karakteristik karya tulis ilmiah pada proposal mahasiswa Fakultas Ekonomi dan Bisnis Universitas Mulawarman. Manajemen pengintegrasian meliputi tahap persiapan, mengajukan judul sebagai bahan penelitian, mencari topik penelitian yang telah dikuasai, meyakinkan bahan bacaan terkait topik mudah untuk diperoleh dan diakses, persempit topik agar penelitian berfokus dan tuntas pembahasannya, memastikan kembali bahwa topik yang akan diambil bermanfaat dan merupakan prioritas yang harus dipecahkan, menelusuri sisi apa yang belum diteliti oleh peneliti lain, bacalah hasil-hasil penelitian terdahulu terkait topik yang relevan minimal lima tahun kebelakang, perhatikan sistematika penulisna proposal, penulisan, pengeditan. Karakteristik karya tulis ilmiah meliputi menyajikan fakta, uaraian pengertian, judul dan permasalahan, menerapkan teori, pemecahan masalah, dan simpulan. Berikut pembahasan lanjut mengenai analisis manajemen pengintegrasian dan karakteristik karya tulis ilmiah pada proposal mahasiswa Fakultas Ekonomi dan Bisnis Universitas Mulawarman.

Dari pemaparan di atas, dalam menulis karya tulis ilmiah pada proposal mahasiswa Fakultas Ekonomi memiliki sistem manajemen pengintegrasian sedikit berbeda yakni tidak di cantumkannya jadwal penelitian dan masih ditemukannya ketidak tepatan dalam penulisan ejaan, dan ditemukan adanya kalimat-kalimat yang tidak efektif atau kalimat-kalimat yang tidak utuh. Peran dosen pembimbing sendiri sanagat penting untuk mengarahkan mahasiswa ketika melakukan konsultasi mengenai karya tulis ilmiah berupa proposal. Pemnimbing yang aktif mengarahkan saat melakukan konsultasi sangat berpengaruh dalam penulisan karya tulis ilmiah karena, dari konsultasi tersebut mahasiswa diarahkan dan diberikan saran-saran agar penulisan karya tulis ilmiah bisa lebih baik dan agar kesalahan dalam ejaan maupun dalam penulisan kalimat tidak ditemukan kembali kesalahan.

Dari pemaparan di atas penulis membuat data rekapitulasi dari data 1 , data 2, dan data 3 sebagai berikut.

Tabel 7. Rekapitulasi Manajemen Pengintegrasian

\begin{tabular}{|c|c|c|}
\hline No & $\begin{array}{c}\text { Manajemen } \\
\text { Pengintegrasian }\end{array}$ & Keterangan \\
\hline 1 & Data 1 & $\begin{array}{l}\text { Manajemen pengintegrasian pada proposal dengan nama penulis } \\
\text { Monalisa, dilihat dari pengeditan terdapat data yang perlu diperbaiki } \\
\text { seperti lebih memperhatikan kembali sistematika dalam penulisan } \\
\text { proposal dan penggunaan pembubuhan dalam awalan kata, dari penulisan } \\
\text { sendiri terdapat kesalahan dalam penulisan ejaan sehingga terdapat kata } \\
\text { yang tidak utuh. }\end{array}$ \\
\hline 2 & Data 2 & $\begin{array}{l}\text { Manajemen pengintegrasian pada proposal dengan nama penulis Elfiana } \\
\text { Septiya Rini. Terdapat Proses pengeditan seperti cara penulisan ejaan yang } \\
\text { kurang tepat, penggunaan kalimat efektif yang kurang tepat. Dan } \\
\text { penulisan paragraf yang tidak sesuai dengan syarat-syarat penulisan } \\
\text { paragraf. }\end{array}$ \\
\hline 3 & Data 3 & $\begin{array}{l}\text { Manajemen pengintegrasian pada proposal dengan nama penulis Triana } \\
\text { Puspita Sari. Terdapat proses pengeditan dimulai dari cara penulisan } \\
\text { bahasa asing yang kurang tepat. Penggunaan kalimat efektif dan penulisan }\end{array}$ \\
\hline
\end{tabular}


paragraf.

Tabel 8. Karakteristik Karya Tulis Ilmiah

\begin{tabular}{|c|c|c|}
\hline No & $\begin{array}{c}\text { Karakteristik } \\
\text { Karya tulis Ilmiah }\end{array}$ & Keterangan \\
\hline 1 & Data 1 & $\begin{array}{l}\text { Karakteristik pada proposal dengan nama penulis Monalisa. } \\
\text { Menyajikan fakta secara objektif dengan memaparkan beberapa bukti salah } \\
\text { satunya adanya Persyaratan Standar Akuntasi Pemerintahan atau PSAP } \\
\text { No.7 tahun } 2010 \text { tentang Aset bersejarah yang di jadikan sebagai acuan. } \\
\text { Dalam uraian pengertian, judul dan permasalahan bersifat Deskriptif dan } \\
\text { analisis. Penerapan teori pada data } 1 \text { secara spesifik dilihat dari PSAP yang } \\
\text { digunakan sebagai tolak ukur akuntansi aset negara. Pemecahan masalah } \\
\text { data } 1 \text { dengan cara induksi dengan memaparkan terlebih dahulu masalah } \\
\text { yang bersifat khusus kemudian mencari konklusi bersifat umum. Data } 1 \\
\text { menyimpulkan secara deduktif dengan memaparkan permasalahan secara } \\
\text { umum seperti memaparkan pembagian akuntansi dan dan penggunaan } \\
\text { akuntansi dalam suatu bidang. }\end{array}$ \\
\hline 2 & Data 2 & $\begin{array}{l}\text { Proposal dengan nama penulis Elfiana Septiya Rini ini menyajikan fakta } \\
\text { secara objektif yakni mengenai kinerja pegawai Puskesmas Merancang. } \\
\text { Uraian pengertian, judul dan permasalahan dipaparkan secara deskriptif } \\
\text { analisis karena dalam proposal tersebut menguraikan mengenai kualitas } \\
\text { sumber daya manusia atau pegawai dapat diukur dari kinerja pegawai. } \\
\text { Penerapan teori pada proposal ini bersifat faktual dilihat dari penjelasannya } \\
\text { hubungan antara hubungan beberapa indikator yang mempengaruhi } \\
\text { lingkungan kerja. } \\
\text { Penguraian masalah pada proposal ini dengan cara induksi mengenai } \\
\text { hubungan faktor-faktor yang mempengaruhi kenerja pegawai di tempat } \\
\text { kerja. Kemudian menyimpulkan dengan cara induktif seperti } \\
\text { mendeskripsikan permasalahan dalam lingkungan kerja. }\end{array}$ \\
\hline 3 & Data 3 & $\begin{array}{l}\text { Penyajian fakta pada proposal dengan nama penulis Triana Puspita Sari } \\
\text { bersifat fakta dan sistematis karena proposal ini memaparkan berdasarkan } \\
\text { data survei angkatan kerja nasional mengenai jumlah pekerja anak di bawah } \\
\text { umur sejak tahun } 2013 \text { yang dipaparkan hingga tahun } 2017 \text {. Uraian } \\
\text { pengertian, judul dan permasalahan pada proposal ini bersifat yang } \\
\text { didasarkan pada konsep-konsep keilmuan atau sudut pandang tertentu. } \\
\text { Penerapan teori dipaparkan secara faktual hal ini dijelaskan adnaya teori } \\
\text { strategi kelangsungan rumah tangga yang memaparkan adanya kesamaan } \\
\text { faktor yang dialami anak-anak yang bekerja di bawah umur di Samarinda. } \\
\text { Penguraian masalah pada proposal ini secara deduksi seperti masalah faktor } \\
\text { ekonomi yang banyak menjadi latar belakang anak bekerja di bawah umur } \\
\text { sampai memiliki pendidikan yang terabaikan. }\end{array}$ \\
\hline
\end{tabular}

Dari ketiga data rekapitulasi di atas, penulis dapat simpulkan mengenai manajemen bahasa penulisan proposal mahasiswa Fakultas Ekonomi Universitas Mulawarman. Dari ketiga data tersebut mengalami proses pengeditan proposal salah satunya, yaitu pada penulisan dan kurang memperhatikan sistematika dalam penulisan proposal, pada proposal mahasiswa Fakultas Ekonomi tidak mencantumkan jadwal penelitian yang menjadi acuan utama peneliti hanyalah 
melalui lembar konsultasi untuk mengukur waktu penelitian. Dalam sistematika proposal mahasiswa mengacu pada sistematika secara umum, seperti kita ketahui bahwa ada beberapa sistematika proposal yang dapat diterapkan seperti sistematika menurut Hapsari, ada terdapat 11 sistematika penulisan yang dipaparkan. Dari sistematika tersebut yang membuat berbeda dengan sistematika di Fakultas Ekonomi, yaitu adanya plagiarisme. Plagiarisme merupakan tindakan menyalin atau meminjam baik gagasan, frasa atau kalimat dari milik karya orang lain. Seiring perkembangan zaman plagiarisme mudah untuk dilakukan karena mudahnya mengakses sumber, dapat dilakukan melalui akses internet atau sumber yang berbasis internet ataupun melalui situs website. Plagiarisme proses yang sangat mudah dalam melakukannya karena prosesnya hanya menyalin dan menempel sehingga ini adalah slaah satu yang menjadi sesuatu yang harus dihindari karena dapat merugikan pihak terkait.

Adanya plagiarism ini mahasiswa dapat melakukan kegiatan pengukuran atau mengukur tingkat plagiarism dalam proposal penelitian karena tidak jarang sebagian mahasiswa akan melakukan tindakan menyalin karya orang lain untuk dijadikan sebagai karya yang dihasilkannya sendiri, agar hal tersebut dapat dihindari maka mahasiswa bisa mencoba menerapkan sistematika proposal.

Selain manajemen pengintegrasian yang dipaparkan oleh Hapsari, terdapat juga lima karakteristik menurut Suherli seperti bagaimana menyajikan fakta dalam proposal secara objektif yang memaparkan atau mengungkapkan sesuatu secara apa adanya, dalam uraian pengertian judul dan permasalahan ketiga proposal tersebut menyajikan secara deskriptif analisis, yaitu penguraian suatu objek yang dipaparkan menjadi kebagian- bagian yang lebih terperinci, dan di dalam setiap bagian didefinisikan lagi sehingga memperjelas definisi bagian utamanya. Penerapan teori pada ketiga data tersebut dipaparkan secara spesifik dan faktual, yaitu mengenai teori-teori yang dipaparkan atau telah diulas oleh beberapa ahli untuk memperkuat proposal penelitian. pemecahan masalah pada ketiga data tersebut terdiri dari 2 berproses secara induksi dengan menguraikan terlebih dahulu permasalahan yang bersifat khusus kemudian mencari suatu konklusi atau simpulan yang bersifat umum dan 1 berproses secara deduksi yang menguraikan terlebih dahulu permasalahan bersifat umum menuju simpulan yang khusus. Setelah pemecahan masalah selanjutnya kesimpulan dari ketiga proposal tersebut.

\section{PENUTUP}

Setelah melakukan analisis data proposal mahasiswa nonkebahasaan Fakultas Ekonomi dengan fokus penelitian manajemen bahasa penulisan proposal, dapat ditarik simpulan sebagai berikut. Tahapan manajemen bahasa penulisan proposal mencakup beberapa tahap berikut ini.

1. Tahap Perencanaan, yakni tahapan penulis merencanakan dengan menentukan topik yang dituangkan isi proposal, dengan:

a. mengajukan judul sebagai bahan penelitian;

b. mencari topik penelitian yang telah dikuasai;

c. meyakinkan bahan bacaan terkait topik mudah diperoleh/mudah diakses;

d. persempit topik agar penelitian berfokus dan tuntas pembahasannya;

e. memastikan kembali bahwa topik yang akan diambil bermanfaat dan merupakan prioritas yang harus dipecahkan; 
f. mengumpulkan data dan informasi selengkap mungkin dari berbagai sumber;

g. menelusuri sisi apa yang belum diteliti oleh peneliti lain;

h. bacalah hasil-hasil penelitian terdahulu terkait topik yang relevan minimal lima tahun ke belakang; dan

i. perhatikan sistematika penulisan proposal.

2. Pengorganisasian: pada tahap ini dari 11 penulis proposal telah menyusun struktur organisasi (struktur organisasi proposal) dengan membuat kerangka proposal.

3. Tahap Penulisan: Setelah topik dituangkan dalam judul dan disetujui oleh dosen pembimbing dituangkan dalam proposal.

4. Pengeditan, mengacu pada karakteristik karya tulis ilmiah.

Selain manajemen, penulis menganalisis karakteristik karya tulis ilmiah pada data 1 , data 2 , data 3 sebagai berikut.

a. Data 1 menyajikan fakta terdapat 2 data, uraian pengertian, judul dan permasalahan terdapat 2 data, menerapkan teori terdapat 1 data, pemecahan masalah terdapat 1 data, dan simpulan terdapat 1 data.

b. Data 2 menyajikan fakta terdapat 1 data, uraian pengertian, judul dan permasalahan terdapat 1 data, menerapkan teori terdapat 1 data, pemecahan masalah terdapat 1 data, dan simpulan terdapat 1 data.

c. Data 3 menyajikan fakta terdapat 2 data, uraian pengertian, judul dan permasalahan terdapat 4 data, pemecahan masalah terdapat 1 data, dan simpulan terdapat 1 data.

\section{DAFTAR PUSTAKA}

Agustrian, N. L., Rizkan, \& Izzudin, M. (2018). Manajemen Program Life Skill Di Rumah Singgah Al-Hafidz Kota Bengkulu. Journal of Community Development, 1(1), 7-12. https://ejournal.unib.ac.id/index.ph $\mathrm{p} / \mathrm{jpls} /$ article/view/4031/2238

Ahmadi, R. (2016). Metode Penelitian Kualitatif. Yogyakarta: Ar-Ruzz Media.

Barnawi \& M. Arifin. (2016). Teknik Penulisan Karya Ilmiah. Yogyakarta: Ar-Ruzz Media.

Dalman. (2014). Keterampilan Menulis. Jakarta: PT Raja Grafindo Persada.

Dalman. (2016). Menulis Karya Ilmiah. Jakarta: PT Raja Grafindo Persada.

Emzir. (2017). Metodologi Penelitian Pendidikan. Jakarta: PT Raja Grafindo Persada.

Yanti, P. G., Zabadi, F., \& Rahman, F. (2016). Bahasa Indonesia Konsep Dasar dan Penerapan. Jakarta: PT Grasindo.

Wijayanti, S. H., Candrayani, A., Hendarwati, I. E. S., \& Agustinus, J. W. (2015). Bahasa Indonesia Penulisan dan Penyajian Karya Ilmiah. Jakarta: PT Raja Grafindo Persada.

Kusmana, S. (2010). Merancang Karya Tulis Ilmiah. Bandung: Remaja Rosdakarya.

Mahsun. (2017). Metode Penelitian Bahasa Tabapan, Strategi, Metode, dan Tekniknya. Edisi Ketiga. Jakarta: PT Raja Grafindo Persada.

Mustari, M. (2015). Manajemen Pendidikan. Jakarta: PT Raja Grafindo Persada. 